\title{
VIEWPOINTS
}

\section{Islam and Democracy}

\author{
Mohammad Hashim Kamali*
}

RELIGIOUS VIEWPOINT: A democratic system of rule is on the whole acceptable to Islam.

Muslim scholars have differed in their assessment of democracy and constitutionalism from the viewpoint of Islamic principles. The view has gained ground, however, that a democratic system of rule is on the whole acceptable to Islam. This acceptance is because democracy is about fundamental rights and liberties, the rule of law, a representative and participatory government, separation of powers and equality before the law. Rights and liberties are a manifestation of human dignity which must be protected against the coercive power of the state. A constitution is also an instrument of limitation, organisation and division of power among the various organs of state.

Broadly, Islam approves of most of these concepts and takes affirmative positions on the protection and realisation of people's welfare and maslahah, a consultative government committed to accountability (muhasabah) and justice. Islam advocates a limited government, which is committed to the advancement of the goals and purposes (maqasid) of Shariah. Islam and democracy both seek to realise people's welfare and basic rights of life, personal security, privacy and ownership. The Shariah recognises these, as also the rights to education and employment, and the individual's entitlement to the essentials of life.

There is much evidence to suggest that Islam envisages a civilian system of rule, not a theocracy. Because the head of state is elected by the people through consultation, nomination and pledge of allegiance (bay'ah), this process translates into the modern day equivalent of a popularly elected government in which the locus of authority rests with the people. The head of state is accountable to the people and subject to the court of justice, and the people have the authority ultimately to depose him in the event of flagrant violation and miscarriage of duty. The head of state has no papal authority to exonerate sin or to interfere with the religion of a person. The civilian character of his office is thus manifested in the legal maxim of fiqh that "the affairs of the head of state are judged by reference to public interest (amr al-imama manut bi'l-maslahah)". The essence of stewardship in Islam is proclaimed in the hadith that "the leader of the people is their servant (sayyid al-qawmi khadimuhum)". 
Yusuf al-Qaradawi approves of democracy and the electoral process, with the latter being tantamount to testimony (shahadah), in that by voting for a candidate, the people testify to the suitability and trustworthiness of the person, and giving shahadah is a collective obligation (fard kifa' $i$ ) of the Muslim community. Party politics, according to al-Qaradawi, is a means of organised participation in government affairs. This too resembles the fiqh schools, or madhhabs, which the learned scholar has characterised as juridical parties, manifesting differences in jurisprudence.

As to the question that democracy is a Western rather than an Islamic doctrine and that it carries Western values and viewpoints, al-Qaradawi responds that Islamic tradition and scholarship have maintained a relatively open profile of receptivity and contribution to other civilisations. It has taken from other traditions that which is of merit and acceptable to its own values. Electoral democracy does not authorise the people or government to change the beliefs of Islam ('aqa'id) nor any of its devotional principles ('ibadat), the halal and haram, and the essentials of morality. These are firmly grounded in the Quran and Sunnah and no one may in the name of democracy interfere with them. As for the management of community affairs and realisation of people's welfare, democracy is more likely to facilitate these than obstruct and undermine. Hence democracy is not contrary to Islam. The Islamic public law doctrine of Shariahoriented policy (siyasah shar'iyyah) also enables the ruling authorities to address urgent issues and problems that affect people's lives through Shariah-compliant ordinances and initiatives, even at the expense of some unavoidable departure from the rulings of the existing schools and scholars.

On the subject of sovereignty which belongs to the people, the constitution, or Parliament (France, the United States, and the United Kingdom respectively), it is not an Islamic doctrine but an aspect of political democracy over which Islamic scholars have expressed reservations. Yet many have also drawn a distinction between what they term as absolute sovereignty (siyadat al-hukm), which can make or unmake any law, and executive sovereignty (al-sultan al-tanfidhi). Only the latter obtains in Islamic polity, simply because it is not vested with the authority to change the essentials of Islam and Shariah.

Hence what remains is a kind of executive sovereignty in which political authority is vested in the people and government exercises it on their behalf.

The challenge facing Islamic scholars in Malaysia and elsewhere is perhaps to highlight aspects of harmony between Islam and democracy, and for the government authorities to set in place rules and procedures to ascertain unity and integration of values, of both Islam and democracy, in its legislative processes, with the purpose ultimately to eliminate or minimise the duality of laws in favour of substantive integration and unity. Another aspect of this challenge is 
to enhance human rights and integrate these principles into the applied laws and procedures of both civil law and Shariah.

Democracy in this digital age presents new challenges to the people's right of privacy, which demands enhanced vigilance from the standpoint of both the Shariah and civil law.

There is also a need to specify with greater clarity what roles the media and education should play in the advancement of both democracy and Islam. It must be added, however much in passing, that Malaysia is not new to most of these challenges, and some work is also underway on the harmonisation of Shariah and civil laws with the legal system of Malaysia, which has gained a fresh momentum with the milestones of progress Malaysia has made in Islamic banking and finance.

\section{Note}

* Mohammad Hashim Kamali, Founding Chairman and CEO of IAIS Malaysia, graduated from Kabul University, and took his PhD in Islamic and Middle Eastern Law at the University of London in 1969. Professor Dr M.H. Kamali served as Professor of Islamic Law and Jurisprudence at the International Islamic University Malaysia (IIUM, 1985-2007), then Dean of the International Institute of Islamic Thought and Civilization (ISTAC). He also held Visiting Professorships at McGill University's Institute of Islamic Studies; Capital University, Ohio; and the Wissenschaftskolleg, Berlin. A member of the Constitution Review Commission of Afghanistan (2003), he has provided expert legal consultation to the new constitutions of Iraq, the Maldives and Somalia. Eminent authority on Islamic legal studies, he has published over 150 academic articles and 35 texts, including standard textbooks at universities worldwide. 